\title{
PENGARUH SETBACK PADA BANGUNAN DENGAN SOFT STORY TERHADAP KINERJA STRUKTUR AKIBAT BEBAN GEMPA
}

\author{
Rizki Efrida \\ Dosen Pengajar Program Studi Teknik Sipil, Fakultas Teknik, UMSU, Medan \\ Surel : Rizki_Efrida@yahoo.co.id \\ Diterima : 22 Mei 2018; Disetujui : 28 Mei 2018
}

\begin{abstract}
ABSTRAK
Pembangunan konstruksi teknik sipil mengalami perkembangan yang sangat pesat seiring dengan berkembangnya zaman sehingga menuntut kita lebih kreatif dalam perancangan struktur baik dalam bentuk bangunan beraturan maupun tidak beraturan yaitu, bangunan setback dan bangunan soft story. Di Indonesia, tantangan yang dihadapi dalam kontruksi gedung bertingkat adalah adanya resiko akibat gempa. Salah satu metode untuk menganalisis beban gempa adalah analisis pushover. Analisis pushover merupakan prosedur analisis untuk mengetahui perilaku keruntuhan suatu bangunan terhadap gempa. Penelitian dilakukan untuk mengetahui seberapa besar pengaruh setback dan soft story yaitu bangunan tanpa dinding pengisi pada lantai dasar terhadap kinerja struktur akibat beban gempa berdasarkan hasil kurva pushover. Stuktur bangunan dimodelkan sebagai portal 2 dimensi yang tanpa adanya dinding pengisi pada lantai dasar yaitu terdiri dari 4 model rangka penuh, setback1, setback2, dan setback3. Hasil analisis dalam penelitian ini menunjukkan bahwa kontribusi dinding pengisi yang terbuat dari dinding bata mempengaruhi kekakuan lateral struktur, serta dengan dikuranginya setback pada struktur bangunan mengakibatkan nilai kekakuan semakin kecil sehingga nilai daktilitas semakin besar. Pada struktur gedung rangka penuh dan setback1 lunak kondisi bangunan sudah mengalami rusak parah atau runtuh saat terjadi gempa kuatdikarenakan terbentuknya sendi plastis pada kolom lantai pertama.
\end{abstract}

Kata Kunci : Analisis Pushover, Dinding Pengisi, Setback, Soft Story

\begin{abstract}
The construction of civil engineering construction has developed very rapidly along with the development of the era so it demands that we are more creative in the design of structures both in the form of irregular and irregular buildings ie, setback building and soft story building. In Indonesia, the challenge faced in the construction of multi-storey building is the risk caused by the earthquake. One method to analyze earthquake loads is pushover analysis. Pushover analysis is an analytical procedure to determine the collapse behavior of a building against earthquake. The research was conducted to find out how big the effect of setback and soft story that is building without wall filler on the ground floor to the structure performance due to earthquake load based on the result of pushover curve. The structure of the building is modeled as a 2-dimensional portal without the filler wall on the ground floor consisting of 4 full frame models, setback1, setback2, and setback 3. The results of the analysis in this study indicate that the contribution of wall filler made of brick walls affect the lateral stiffness of the structure, as well as with the reduced setback on the structure of the building resulting in smaller stiffness value so that the greater the ductility value. In full skeletal structure and soft setback1 the condition of the building has been severely damaged or collapsed during a strong earthquake due to the formation of plastic joints in the first floor column.
\end{abstract}

Keywords: Pushover Analysis, Setback, Soft Story, Wall Filler 


\section{Pendahuluan}

Secara geografis Indonesia terletak pada kawasan cincin api (ring of fire) sehingga tak heran bila gempa bumi sering terjadi. Setiap terjadinya gempa resiko yang dihadapi bukan hanya dari segi korban jiwa tetapi juga kerusahan infrastruktur. Salah satu akibat terjadinya kerusakan tersebut dikarenakan pemilihan struktur yang tidak beraturan yaitu, bangunan setback dan bangunan tanpa ada dinding pengisi pada lantai dasarnya (soft strory). Tipe bangunan seperti ini umumnya bertujuan untuk berbagai kepentingan seperti ruang tunggu, tempat parkir, pertokoan sedangkan dibagian atasnya digunakan untuk pusat kegiatan.Pada dasarnya kolom yang mengalami tingkat lunak dapat dikategorikan sebagai kolom yang menerima beban relatif kuat dari struktur diatasnya atau bisa dikatakan suatu tungkat yang lemah, yang kekakuannya jauh lebih kecil daripada tingkattingkat lainnya. Struktur dengan soft story akan memperbesar deformasi lateral dan gaya geser pada kolom.

Terlepas dari berbagai bentuk bangunan yang tidak beraturan dan permasalahan gempa yang terjadi, maka tugas utama dari para ahli konstruksi untuk menciptakan suatu tatanan baru mengenai perancangan bangunan tahan gempa yang lebih baik lagi. Hal tersebut tentunya tidak hanya bertujuan untuk menciptakan struktur bangunan yang lebih kuat dan tahan gempa, tetapi juga bertujuan untuk memberikan keamanan dan kenyamanan bagi setiap orang yang ada dan tinggal di dalam bangunan tersebut. Salah satu metode analisis untuk gedung bertingkat terhadap pengaruh gempa adalah dengan analisis pushover

\section{Kajian Pustaka}

\subsection{Bangunan Setback}

Struktur bangunan setback adalah bangunan apabila bagian atas bangunan yang bersangkutan menjorok kedalam. Bangunan setback baik dalam satu arah maupun dua arah merupakan termasuk dalam bangunan ireguler, karena pusat massa tidak berimpit secara vertikal. Massa dan kekakuan baik kearah horizontal maupun kearah vertikal tidak terdistribusi secara merata. Problem yang akan terjadi pada daerah peralihan kekakuan dari kekakuan yang besar pada bagian bawah ke kekakuan yang relatif lebih kecil pada bagian atas. Seberapa besar problem yang ditimbulkan akan bergantung pada banyak hal, yang diantaranya adalah rasio luasan atas terhadap bagian bawah, ratio tinggi bagian setback terhadap bagian bawah, arah setback (1 atau 2 arah), letak setback (simetris atau tidak) dan sebagainya

\subsection{Bangunan SoftStory}

Salah satu definisi bangunan gedung tidak beraturan adalah adanya suatu tingkat yang lemah, yang kekakuannya jauh lebih kecil dari pada tingkat-tingkat yang lain (soft storey). Didalam SNI 03-2002, TCPKGUBG-2002 atau RSNI 03-1726 (2010) dijelaskan tentang bangunan gedung reguler itu adalah gedung yang sistem strukturnya memiliki kekakuan lateral yang beraturan tanpa adanya tingkat lunak (soft storey). Yang dimaksud dengan struktur tingkat lunak adalah suatu tingkat yang mana kekauan lateralnya kurang dari 70 persen kekakuan lateral tingkat diatasnya atau kurang dari 80 persen kekakuan lateral ratarata 3 tingkat diatasnya,

\subsection{Dinding Pengisi}

Dinding pengisi yang digunakan dalam penelitian ini berupa dinding bata merah, karena banyak digunakan pada bangunanbangunan di wilayah negara Indonesia. Hal ini dikarenakan bata merah memiliki harga yang ekonomis, mudah didapat dan tahan terhadap cuaca.

Dinding pengisi bata biasa digunakan pada struktur bangunan beton bertulang ataupun struktur bangunan baja. Dinding dapat menutupi tembok bangunan secara keseluruhan dan ada juga yang memiliki bukaan untuk pintu dan jendela. Namun dalam perencanaan struktur bangunan, dinding pengisi hanya diperlukan sebagai sekat atau partisi tanpa fungsi struktural. Padahal apabila terjadi gempa dinding pengisi dapat mempengaruhi kekakuan dan kekuatan struktur yang efeknya kadang tidak menguntungkan pada struktur tersebut sehingga dapat menimbulkan kerusakan (Dewobroto, 2005).

\subsection{Metoda Perencanaan Umum \\ 2.4.1 Metoda Dasar}

Portal-isi tunggal yang dibebani secara diagonal sampai tahap puncak ternyata tidak mengalami mekanisme keruntuhan plastis, tetapi hanya mengalami lentur yang besarnya tidak terlalu signifikan 


\section{Pengaruh Setback Pada Bangunan Dengan Soft Story \\ Terhadap Kinerja Struktur Akibat Beban Gempa}

yaitu pada sudut yang tidak dibebani. Selanjutnya diketahui bahwa perilaku portal-isi yang terdiri dari panel ganda hamper sama dan disimpulkan bahwa perilaku portal-isi dengan panel tunggal sama dengan perilaku portal-isi dengan banyak panel seperti yang terdapat pada gedung bertingkat. Konklusi yang dapat diambil bahwa apabila properti mekanik dinding pengisi diperoleh maka selanjutnya dapat dimodelkan sebagai batang diagonal tekan pengganti dan dianalisis seperti struktur rangka umumnya.

\subsubsection{Dagonal Tekan Ekivalen}

Diakitkan dengan struktur portal bertingkat dengan dinding pengisi,$M_{j}$ dapat dihilangkan dari Pers. (2.13), sehingga daya dukung horizontal dari portal isi adalah

$H=\sigma_{c} t\left(1-\alpha_{c}\right) \alpha_{c} h+\tau_{b} t \alpha_{b} l+\left(\frac{2 M_{p j}}{h}\right)$

Term ke-1 dan ke-2 adalah tahanan dinding pengisi, lalu term ke-3 adalah tahanan portal yang dibebani sampai kondisi batas. Dengan demikian bagian dinding pengisi dapat digantikan dengan tahanan penopang ekivalen sebagai berikut:

$$
H=R \cos \theta+\left(\frac{2 M_{p j}}{h}\right)
$$

Sedangkan $\mathrm{R}$ tergantung dari tiga macam keruntuhan yang terjadi dan dipilih yang paling kecil (menentukan).

a. Keruntuhan Sudut / Ujung Diagonal (CC = Corner Crushing)

Mode keruntuhan sudut atau ujung diagonal $(\mathrm{CC}=$ corner crushing $)$ maka tahanan diagonal dapat dihitung dari:

$$
R=R_{C C}=\frac{\left(1-\alpha_{c}\right) \alpha_{c} t h \sigma_{c}+\alpha_{b} t l \tau_{b}}{\cos \theta}
$$

b. Keruntuhan Tekan Diagonal (DC = Diagonal Compression)

Dinding pengisi yang langsing dapat mengalami keruntuhan tekan diagonal ditengah panel. Kehancuran tersebut akibat ketidak-stabilan dinding pengisi akibat timbulnya diagonal tekan yang besarnya dapat dihitung dari:

$$
R=R_{D C}=\frac{0.5 h^{\prime} t f_{a}}{\cos \theta}
$$

Kuat tekan aktual dinding masonri tergantung dari arah tegangan tetapi pendekatan dengan kuat prisma $f_{m}^{\prime}$ dari ACI 530-88 dapat digunakan sehingga

$f_{a}=f_{c}\left[1-\left(\frac{l_{e f f}}{40 t}\right)^{2}\right]$

dimana $f_{c}=0.6 \phi \cdot f_{m}^{\prime}$ dengan $\phi=0.65$

Panjang efektif pita diagonal tergantung dari panjang bidang kontak dan geometri panel pengisi dan secara konservatif dapat diambil sebagai berikut:

$$
l_{\text {eff }}=\sqrt{\left(1-\alpha_{c}\right)^{2} h^{\prime 2}+l^{\prime 2}}
$$

\section{c. Keruntuhan Geser $(S=$ Shear $)$}

Dinding pengisi dari masonri dapat mengalami retak horizontal sepanjang panel akibat gaya geser yang berlebihan. Gaya geser horizontal total yang menyebabkan keruntuhan dapat dihitung sebagai berikut:

$$
H_{s}=\frac{\gamma v l^{\prime}}{1-0.45 \tan \theta^{\prime}}<0.83 \gamma t l^{\prime}
$$

Gaya diagonal tekan yang berkesuaian dengan gaya horizontal tersebut adalah $R=R_{S}=\frac{\gamma v t l^{\prime}}{\left(1-0.45 \tan \theta^{\prime}\right) \tan \theta}<\frac{0.83 \gamma t l^{\prime}}{\cos \theta}$

Dimana 0 diambil $0.25 \mathrm{MPa}$ dan 0.41 $\mathrm{MPa}$ masing-masing untuk dinding masonri tanpa grouting dan dengan grouting, sedangkan $\tan \theta^{\prime}=\left(a-\alpha_{c}\right) h^{\prime} / l^{\prime}$

2.5 Diagonal Tekan Ekivalen (Equivalent Diagonal Strut) Berdasarkan FEMA 273

Lebar efektif diagonal compression strut yang digunakan untuk menganalisis kekuatan dan kekakuan dinding pengisi bata berdasarkan model FEMA 273 dapat dihitung dengan rumus :

$$
\begin{aligned}
a & =0.175\left(\lambda_{1} h_{c o l}\right)^{-0.4} r_{\mathrm{inf}} \\
\lambda_{1} & =\left[\frac{E_{m e} t_{\mathrm{inf}} \sin 2 \theta}{4 E_{f e} \boldsymbol{I}_{c o l} \boldsymbol{h}_{\mathrm{inf}}}\right]^{\frac{1}{4}}
\end{aligned}
$$

dimana:

$\mathrm{h}_{\mathrm{col}}$ : tinggi kolom diantara as-balok

$\mathrm{h}_{\text {inf }} \quad:$ tinggi dinding portal

$\mathrm{E}_{\mathrm{fe}} \quad$ : modulus elastisitas material portal

$\mathrm{E}_{\mathrm{me}}$ : modulus elastisitas material dinding pengisi

$\mathrm{I}_{\mathrm{col}} \quad$ : inersia penampang kolom

$\mathrm{L}_{\mathrm{inf}} \quad$ : panjang dinding pengisi

$r_{\text {inf }}:$ panjang diagonal dinding pengisi

$t_{\text {inf }} \quad$ : tebal dinding pengisi 
$\theta \quad$ : sudut yang dibentuk antara tinggi dan panjang dinding pengisi

$\lambda_{1} \quad$ : koefisien yang digunakan untuk menentukan lebar efektif strut

a

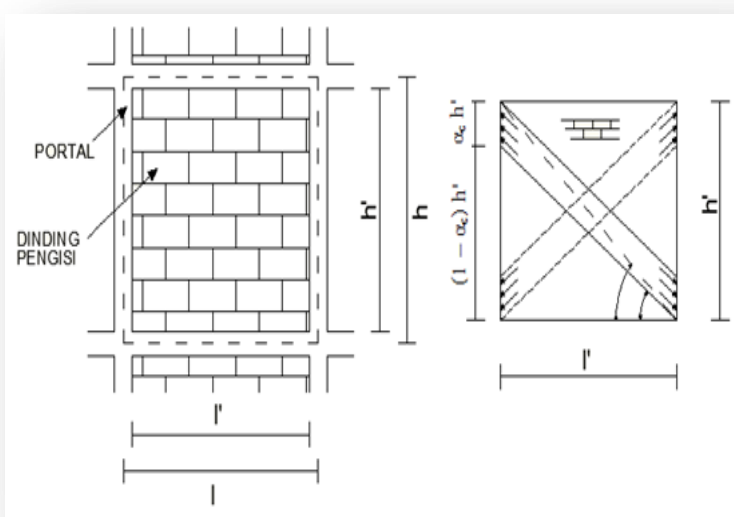

Gambar 1. a) Portal Isi; B) Penopang Diagonal Bolak-Blik (Saneinejad Dan Hobbs, 1995)

\subsection{Prosedur Perhitungan Analisa Pushover}

Analisa statik nonlinier merupakan prosedur analisa untuk mengetahui perilaku keruntuhan dan kapasitas dari suatu struktur secara keseluruhan, mulai dari kondisi elastis, plastis, hingga elemen-elemen struktur mengalami keruntuhan akibat beban gempa. Analisis ini dilakukan dengan cara memberikan pola beban lateral statik pada struktur yang nilainya terus ditingkatkan secara bertahap hingga mencapai target perpindahan (displacement) dari suatu titik acuan. Pada analisis ini yang menjadi titik acuan adalah titik pada lantai atap dan besarnya deformasi maksimum yang boleh terjadi pada struktur ditetapkan terlebih dahulu oleh perencana.

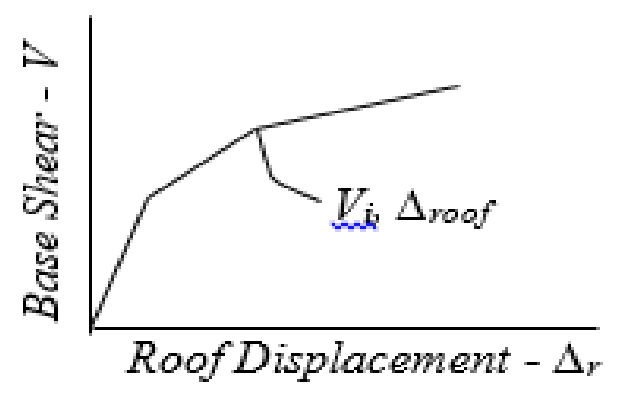

Gambar 2 Kurva kapsitas pushover
Kurva kapasitas pushover

$\Delta_{\text {roof }} \quad: \quad$ Simpangan atap

$V_{i} \quad$ : Gaya geser dasar

W : berat total

Dari kurva pushover dapat ditentukan parameter daktilitas, kekakuan, dan kekuatan. Parameter tersebut mencerminkan perilaku struktur akibat beban lateral (gempa) yang terjadi pada struktur.

\section{Metodologi}

Pada penelitian ini model struktur yang dianalisa adalah bangunan yang terdiri dari 6 lantai dan 3 bentang (Gambar 3.1). Tinggi pada lantai pertama $4 \mathrm{~m}$, sedangkan pada lantai yang lain $3.5 \mathrm{~m}$. Masing-masing panjang bentang $5 \mathrm{~m}$ kecuali dibagian tengah $3 \mathrm{~m}$. Perletakan diasumsikan jepit. Struktur diasumsikan terletak di atas tanah sedang dan berada di zona gempa kuat. Peruntukan bangunan diasumsikan sebagai perhotelan. Untuk preliminary design ditetapkan dimensi balok $40 \times 60 \mathrm{~cm}$, kolom $60 \times 60 \mathrm{~cm}$, dan tebal plat lantai/atap $12 \mathrm{~cm}$.
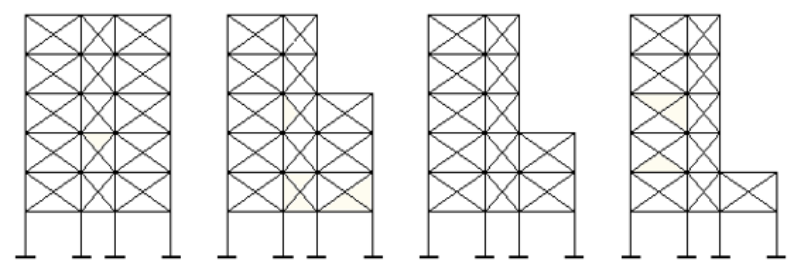

Rangka penuh Setback 1 Setback 2 Setback 3

Gambar 3. Pemodelan Struktur Tanpa Dinding Pengisi Pada Lantai Dasar (Soft Story)

Dalam pelaksanaan penelitian ini diperlukan suatu tahapan penelitian agar dapat membantu dalam menentukan langkah penelitian. Proses tahapan penelitian ini diperlihatkan pada bagan alir pada Gambar 4 . 


\section{Pengaruh Setback Pada Bangunan Dengan Soft Story Terhadap Kinerja Struktur Akibat Beban Gempa}

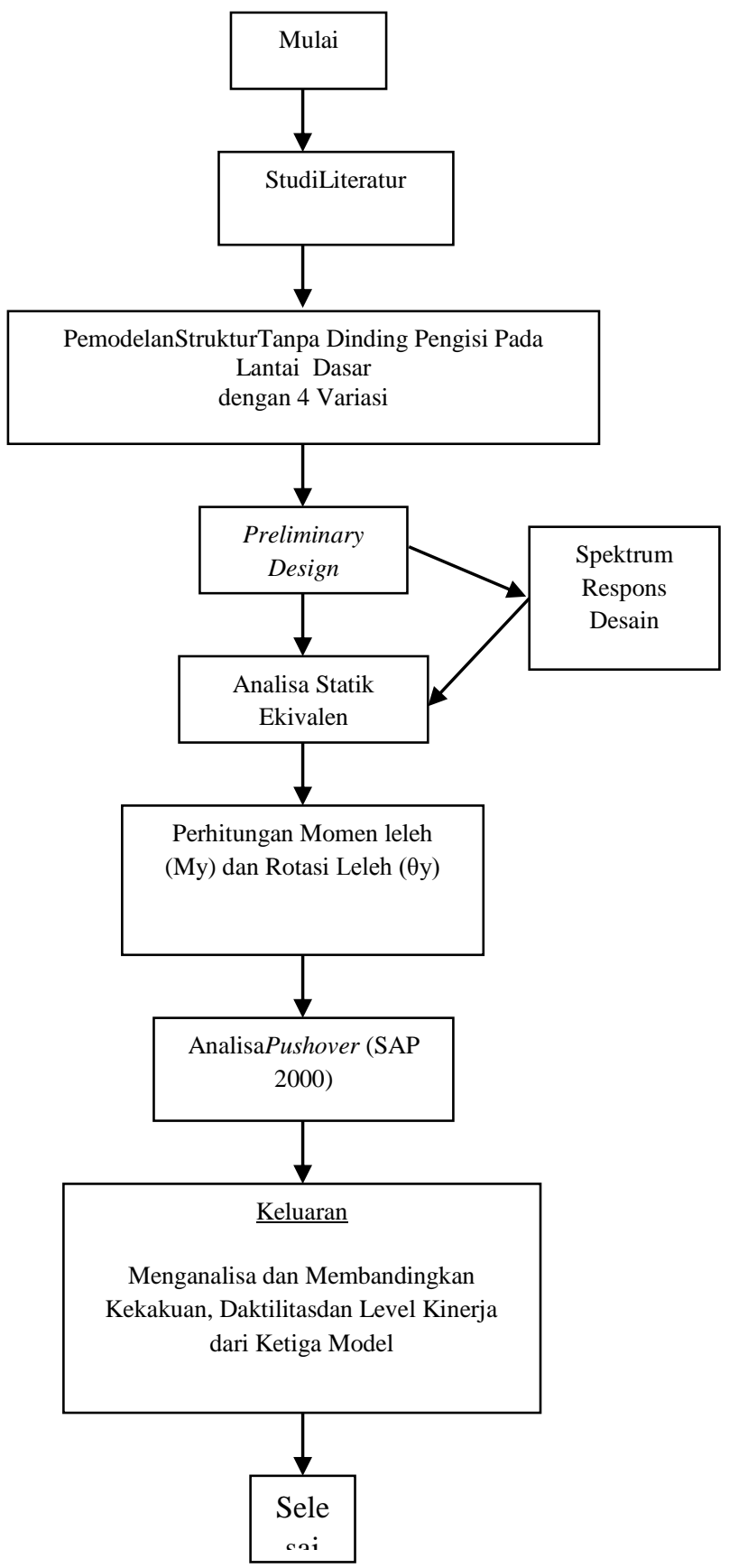

Gambar 4. Bagan Alir Penelitian
4 Hasil dan Pembahasan

\subsection{Hasil Analisa Kurva Kapasitas ATC-40}

Berikut ini akan diuraikan kurva kapasitas dari hubungan antara stuktrur tanpa dinding bata pada lantai dasar (soft story) rangka penuh, setback 1 , setback 2 dan setback 3

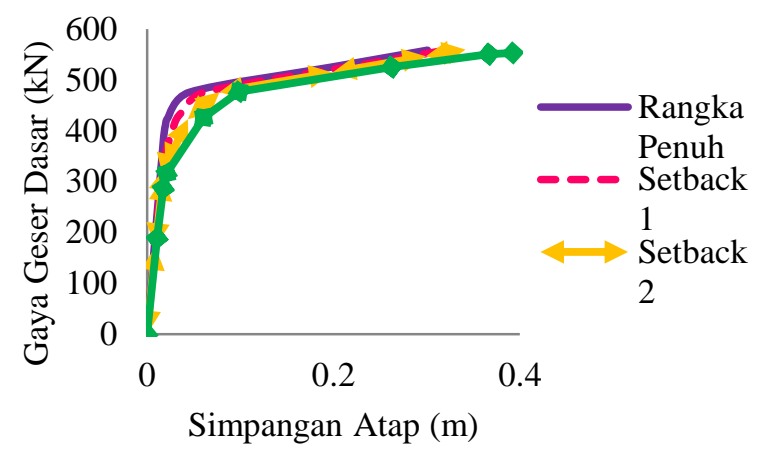

Gambar 5. Perbandingan Kurva Kapasitas Struktur Tanpa Dinding Pengisi Pada Lantai Dasar (Soft Story)

Gambar 5 menunjukkan bahwa struktur rangka penuh memiliki kapasitas terbesar dalam menerima beban gempa dibandingkan struktur gedung setback1, setback2, dan setback3, dan struktur rangka penuh juga memiliki kemampuan berdeformasi pasca elastis lebih kecil dibandingkan struktur setback 3. Struktur setback3 memiliki kemampuan berdeformasi terbesar dan terkecil dalam menerima beban gempa dibandingkan struktur rangka penuh, setback1 dan setback2. Kapasitas struktur setback1 dalam menerima beban gempa lebih besar dibandingkan struktur setback2 namun lebih kecil dibanding struktur rangka penuh. Sifat daktail dari perilaku struktur sistem rangka pemikul momen dimana struktur akan cenderung berdeformasi lebih besar seiring dengan penurunan kapasitas kekuatan dalam menahan gaya lateral.

\subsection{Daktilitas}

Besarnya faktor daktilitas $(\mu)$ diperoleh dari perbandingan perpindahan atap saat mencapai batas ultimit dengan perbandingan atap saat terjadi leleh pertama pada elemen struktur. Gambar berikut ini menunjukkan daktilitas stuktur pada semua model untuk zona gempa 4(gempa tinggi). 


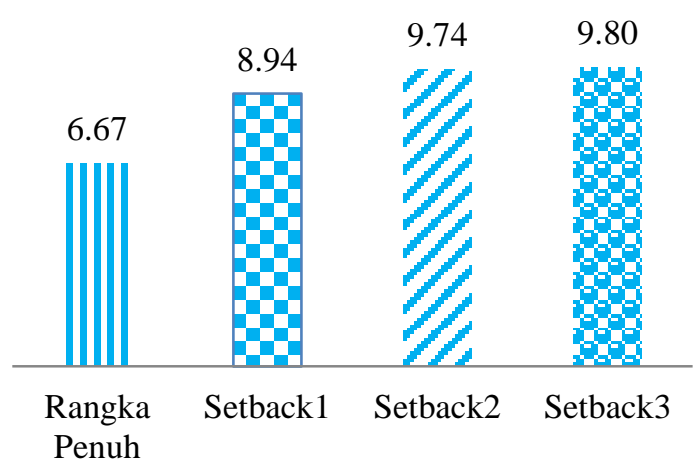

Gambar 6. Perbandingan Daktilitas Struktur Tanpa Dinding Pengisi Pada Lantai Dasar (Soft Story)

Berdasarkan Gambar 6 dapat dianalisis bahwa:

> Struktur setback3 memiliki daktilitas yang lebih besar dari struktur rangka penuh, setback1, dan setback2. Dengan keberadaannya dinding bata bisa mengakibatkan menurunnya daktilitas struktur dan menyebabkan struktur menjadi lebih kaku serta dengan semakin dikuranginya setback pada bangunan akan menghasilkan daktilitas yang lebih tinggi atau besar.

> Persentase terbesar perbedaan daktilitas struktur setback3 adalah mencapai $47.00 \%$ lebih besar terhadap struktur rangka penuh.

\subsection{Kekakuan}

、Kekakuan Elastis (kN/m)

5 Kekakuan Dinding Pasca Elastis (kN/m)

- Kekakuan Pasca Elastis (kN/m)

20572.15

19522.86

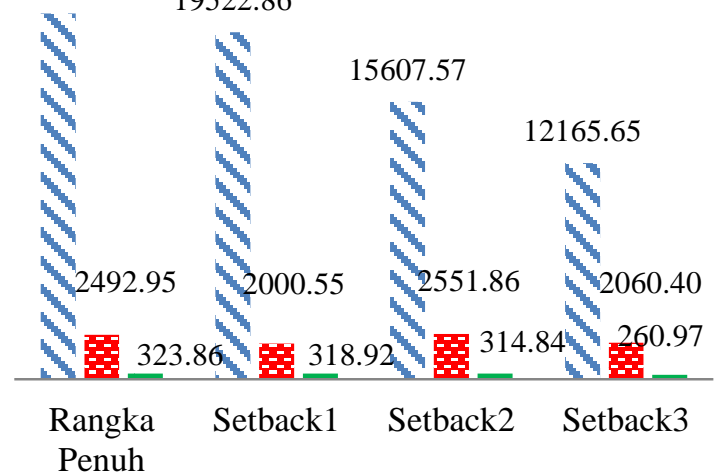

Gambar 7. Perbandingan Kekakuan Elastis, Kekakuan Dinding Pasca Elastis Dankekakuan Pasca Elastis Pada Zona Gempa 6

Berdasarkan Gambar 7 dapat dianalisis bahwa:
Struktur rangka penuh memiliki kekakuan elastis lebih besar dibandingkan struktur setback1, setback 2 dan setback3.

> Persentase terbesar perbedaan kekakuan elastis struktur setback3 adalah mencapai $40.86 \%$ lebih kecil terhadap struktur rangka penuh.

> Struktur setback2 memiliki kekakuan dinding pasca elastis lebih besar dibandingkan struktur rangka penuh, setback1 dan setback3.

> Persentase terbesar perbedaan kekakuan dinding pasca elastis struktur setback1 adalah mencapai $19.75 \%$ lebih kecil terhadap struktur rangka penuh.

- Stuktur rangka penuh memiliki kekakuan pasca elastis lebih besar dibandingkan struktur setback1, setback 2 dan setback3.

- Persentase terbesar perbedaan kekakuan pasca elastis struktur setback3 adalah mencapai $19.42 \%$ lebih kecil terhadap struktur rangka penuh.

\subsection{Simpangan Target}

Simpangan target atau titik kinerja merupakan nilai yang diperoleh dari hasil kurva pushover yang dipengaruhi akibat adanya pembebanan yang bekerja secara lateral. Secara keseluruhan pada model struktur rangka penuh nilai simpangan target lebih besar dari model yang lain, dapat dilihat pada Gambar 8.

\subsection{1}

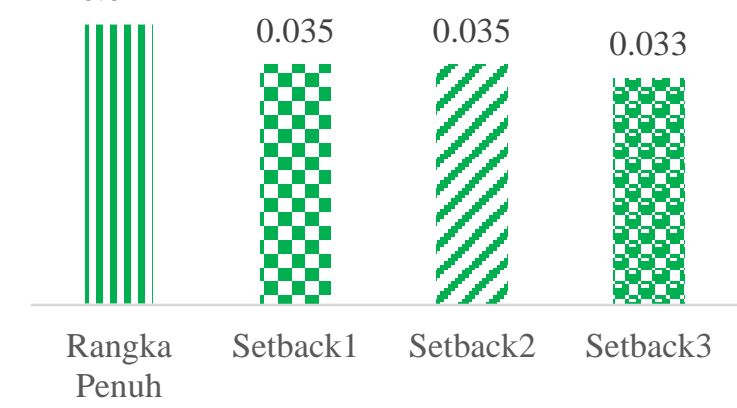

Gambar 8. Perbandingan Simpangan Target Pada Zona 6

Persentase perubahan simpangan target tebesar terjadi pada struktur setback 3 mencapai $19,51 \%$ lebih kecil terhadap struktur rangka penuh.

\subsection{Gaya Geser Dasar}

Pada model struktur rangka penuh mampu menerima gaya geser dasar lebih baik 


\section{Pengaruh Setback Pada Bangunan Dengan Soft Story \\ Terhadap Kinerja Struktur Akibat Beban Gempa}

atau besar dibandingkan dengan model lainnya, dapat dilihat pada Gambar 4.5.

464.876

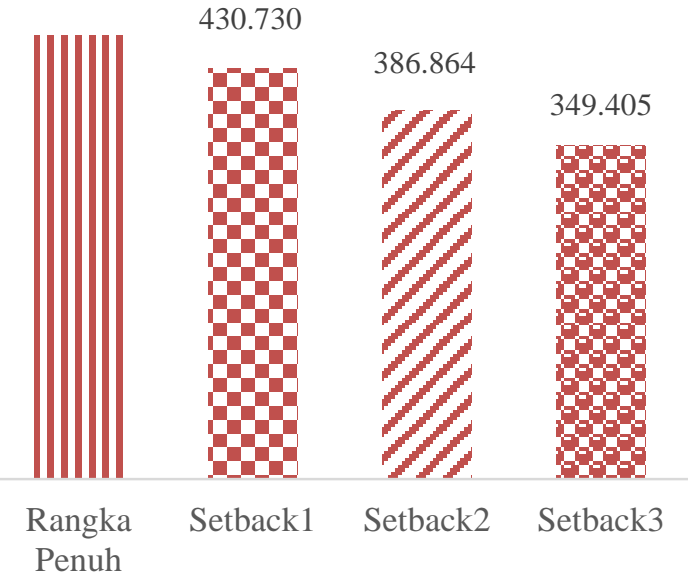

Gambar 9. Perbandingan Gaya Geser Dasar Pada Zona 6

Persentase perubahan gaya geser dasar terbesar terjadi pada struktur setback 3 mencapai $24,84 \%$ lebih kecil terhadap stuktur rangka penuh.

Berdasarkan hasil titik kinerja menurut metoda spektrum kapasitas (ATC-40) pada saat terjadi gempa kuat (zona 6), dapat dianalisa sebagai berikut :

a) Pada struktur setback2 level kinerjanya masih berada di daerah $\mathrm{B}$ to IO yang berarti stuktur masih dalam keadaan baik.

b) Pada struktur setback3 berada di daerah IO to LS yang berarti struktur masih dalam keadaan baik.

c) Pada struktur rangka penuh dan setback1 sudah berada di daerah $D$ to $E$ yang berarti stuktur sudah runtuh total, dikarenakan terbentuknya sendi plastis pada kolom lantai pertama.

\section{Simpulan}

Dari hasil penelitian ini diperoleh kesimpulan sebagai berikut:

1) Keberadaan dinding bata bisa mengakibatkan menurunnya daktilitas struktur dan menyebabkan struktur menjadi lebih kaku serta dengan semakin dikuranginya setback pada bangunan struktur mengakibatkan daktilitas semakin naik atau besar.

2) Keberadaan dinding bata bisa mengakibatkan struktur menjadi lebih kaku dan menyebabkan menurunnya daktilitas struktur serta dengan semakin dikuranginya setback pada bangunan struktur mengakibatkan kekakuan semakin turun atau kecil.

3) Pada struktur gedung rangka penuh dan setback1 lunak kondisi bangunan sudah mengalami rusak parah atau runtuh saat terjadi gempa kuatdikarenakan terbentuknya sendi plastis pada kolom lantai pertama

\section{Daftar Pustaka}

Antonius dan Widhianto, A. (2013). Soft Strorey pada Respon Dinamik Struktur Gedung Beton Bertulang Tingkat Tinggi (199S). Universitas Sebelas Maret. Surakarta.

Aryanto, A. 2008. Kinerja Portal Beton Bertulang dengan Dinding Pengisi Bata Ringan terhadap Beban Gempa. Tesis Magister, Institusi Teknologi Bandung, Bandung.

Asim, B., dkk. (2014). Effect of Soft Storey on the Seismic Behaviour Muti-Storey Building-an Experimental Study. International Journal of Advanced Technology in Engineering and Science.

Asteris, P. G. 2003. Lateral stiffness of brick masonary infilled planed frame. Journal of Struktural Engineering, ASCE, 129(8), 1071-1079.

ATC-40 (1996). Seismic Evaluation and Retrofit of Concrete Buildings. Report SSC 96-01, California Seismic Safety Commission, Penerbit: Applied Technology Council, Redwood City.

Badan Standarisasi Nasional. Tata Cara Perencanaan Ketahanan Gempa Untuk Bangunan Gedung (SNI 03-1729-2002.)

Berny, A. E. R. (2013). Perhitungan Inter Story Drift Pada Bangunan Tanpa Set-back dan Dengan Set-back Akibat Gempa. Jurnal Sipil Statik, Vol. 1.

Carvalho, G., Rita, B., \& Carlos, B. (2012). NonlinearStatic and Dynamic Analyses of Reinforced Concrete Buildings-Comparison of Different Modelling Approaches. Portugal. 
Chopra, A. (2001). Dynamics of Structures: Theory and Applications to Earthquake Engineering. Penerbit: Prentice Hall, New York.

Dewobroto, W. (2005). Analisa Inelastis Portal Dinding Pengisi dengan "Equivalent Diagonal Strut". Jurnal Teknik Sipil, Vo; 12 .

Dewobroto, W. (2005). Evaluasi Kinerja Struktur Baja Tahan Gempa dengan Analisa Pushover. Universitas Pelita Harapan.

Faisal, A. (2013). Pemodelan Getaran Gempa Struktur Beton untuk Analisis Tidak Linier. Seminar Nasional IV HASTAG, Medan.

Hejazil, F., dkk. (2011). Effect of Soft Story on Structural Response of High Rise Buildings. Material Science and Engineering.

Saneinejad, A. dan Hobbs, B. 1995. Inelastic design of infilled frames. Journal of Structural Engineering, ASCE, 121(4), 634-650.

Sitompul, M. (2015). Studi Parametrik Kinerja Dinding Pengisi Bata Merah pada Struktur Beton Bertulang Akibat Beban Gempa. Tesis, Program Studi Teknik Sipil. Universitas Sumatera Utara.

Wibisono, C. dan Lie, H. (2008). Modal Pushover Analysis Struktur Gedung Beton Bertulang di Bawah Pengaruh Beban Gempa Kuat. Laporan Tugas Akhir, Program Studi Teknik Sipil, ITB, Bandung.

Widodo. (2012). Seismologi Teknik \& Rekayasa Kegempaan. Jogjakarta: Pustaka Pelajar 